\title{
Different Secretory Response of Pancreatic Islets and Insulin Secreting Cell Lines INS-1 and INS-1E to Osmotic Stimuli
}

\author{
M. OREČNÁ, R. HAFKO, Z. BAČOVÁ, J. PODSKOČOVÁ ${ }^{1}$, D. CHORVÁT Jr. ${ }^{1}$, \\ V. ŠTRBÁK
}

Institute of Experimental Endocrinology, Center of Excellence of the Slovak Academy of Sciences, Bratislava, and ${ }^{1}$ International Laser Center, Bratislava, Slovakia

Received July 9, 2007

Accepted October 10, 2007

On-line November 30, 2007

\begin{abstract}
Summary
Objective of this study was to characterize osmotically-induced insulin secretion in two tumor cell lines. We compared response of freshly isolated rat pancreatic islets and INS-1 and INS-1E tumor cell lines to high glucose, $30 \%$ hypotonic medium and $20 \%$ hypertonic medium. In $\mathrm{Ca}^{2+}$-containing medium glucose induced insulin release in all three cell types. Hypotonicity induced insulin secretion from islets and INS-1 cells but not from INS-1E cells, in which secretion was inhibited despite similar increase in cell volume in both cell types. $\mathrm{GdCl}_{3}(100 \mu \mathrm{mol} / \mathrm{l})$ did not affect insulin response from INS-1E cells to hypotonic challenge. Hypertonic medium inhibited glucose-induced insulin secretion from islets but not from tumor cells. Noradrenaline (1 $\mu \mathrm{mol} / \mathrm{l}$ ) inhibited glucose-induced but not swelling-induced insulin secretion from INS-1 cells. Surprisingly, perifusion with $\mathrm{Ca}^{2+}$-depleted medium showed distinct secretory response of INS-1E cells to hypotonicity while that of INS-1 cells was partially inhibited. Functioning glucose-induced insulin secretion is not sufficient prerequisite for hypotonicity-induced response in INS$1 \mathrm{E}$ cells suggesting that swelling-induced exocytosis is not essential step in the mechanism mediating glucose-induced insulin secretion. Both cell lines are resistant to inhibitory effect of hyperosmolarity on glucose-induced insulin secretion. Response of INS-1E cells to hypotonicity is inhibited by the presence of $\mathrm{Ca}^{2+}$ in medium.
\end{abstract}

\section{Key words}

Cell volume - Insulin secretion • Pancreatic islets • Tumor cell line $\bullet \mathrm{Ca}^{2+}$ and exocytosis

\section{Corresponding author}

V. Štrbák, Institute of Experimental Endocrinology, Slovak Academy of Sciences, Vlárska 3, 83306 Bratislava, Slovakia. Fax: +4212 54774809. E-mail: vladimir.strbak@savba.sk

\section{Introduction}

Cell volume regulation in response to osmotic challenge is integrated into a signal transduction network regulating various cell functions (Lang et al. 1998a, b, Jakab et al. 2002, Wehner et al. 2003). Cell swellinginduced peptide secretion represents an important cellular reaction when material stored in secretory vesicles is expulsed as a secretory burst of peptide hormones or enzymes from various types of cells including endocrine, neurons, leukocytes or those of the exocrine pancreas (Štrbák and Greer 2000). Dynamics of the secretory response to cell swelling is similar to that induced by other specific or non-specific secretagogues (Bačová et al. 2006a). The cell swelling as a nonspecific stimulator of protein/peptide release with limited selectivity (Najvirtová et al. 2003, Bačová et al. 2005) is a suitable tool for characterization of peptide secretion from various cells and tissues (Štrbák and Greer 2000, Štrbák 2006). Although the mechanism of swelling-induced exocytosis is not fully understood, its comparison with signal transduction mediating glucose-induced insulin secretion indicates the presence of novel signaling pathway (Bačová et al. 2005). Hyposmotic stimulation of insulin secretion from pancreatic islets is independent of both the extracellular and intracellular $\mathrm{Ca}^{2+}$ (Blackard et al. 1975, Straub et al. 2002, Bačová et al. 2005), various insulin release inhibitors and ion-flux modifiers (Blackard et al. 1975, Straub et al. 2002), cannot be inhibited by noradrenaline (Bačová et al. 2005), does not involve protein kinase C (Bačová et al. 2005), $\mathrm{G}$ proteins or phospholipase $\mathrm{A}_{2}$ activation and is $\mathrm{N}$-ethyl maleimide insensitive (Bačová et 
al. 2007). Interestingly, glucose itself induces swelling of pancreatic B-cells (Miley et al. 1997) and tumor-derived INS-1E cells (Jakab et al. 2006); therefore a possibility that swelling is integrated into glucose signaling should be also considered.

Secretion induced by extracellular hyposmo-larity is due to the relative reduction of extracellular compared to intracellular osmolarity and not to dilution of any essential extracellular elements. If medium is made by the addition of equivalent osmolar amount of mannitol (Greer et al. 1983), sorbitol (Blackard et al. 1975, Straub et al. 2002), choline chloride (Blackard et al. 1975) or by biologically inactive L-glucose (Nikodémová et al. 1999) to maintain isosmolarity on both sides of the plasma membrane, no secretion is induced. If the medium is made hyperosmolar, secretion is not stimulated and is often suppressed (Sato et al. 1990, Miley et al. 1997, Najvirtová et al. 2003, Wang et al. 1992, Kučerová and Štrbák 2001). However, on return of the cells to an isosmolar medium, there is a prompt dose-related burst of 'off response' secretion the magnitude of which is proportional to that of the preceding hyperosmolarity (Greer et al. 1985). This indicates that it is the relative difference in intracellular vs. extracellular osmolar concentration which causes exocytosis rather than the absolute osmolarity of either compartment.

The aim of the present study was to compare glucose- and osmotically-induced insulin secretion from different insulin secreting systems: freshly isolated pancreatic islets and rat insulinoma cell lines INS-1 and INS-1E. The differences in secretory responses between these cells may provide an important insight into the mechanisms of insulin secretion induced by cell swelling.

\section{Material and Methods}

All animal-use protocols conformed to the guiding principles of the European Convention on Animal Protection and were approved by the Ethical Committee of the Institute of Experimental Endocrinology SAS and the national Veterinary Board.

Male Wistar rats (Charles River, Sulzfeld, Germany) (300-350 g) were kept under controlled temperature $\left(22-24{ }^{\circ} \mathrm{C}\right)$ and constant $12 \mathrm{~h}$ light/dark cycle, fed with Purina Chow and tap water ad libitum.

\section{Tumor cell lines}

\section{Rat insulinoma derived $\beta$ cells}

Rat insulin-secreting cell lines INS-1 and INS1E sensitive to glucose stimulation (Merglen et al. 2004), were a kind gift from Dr. Claes B. Wollheim (University Medical Center, Geneva, Switzerland). Cells were cultivated at $37{ }^{\circ} \mathrm{C}$ in humidified atmosphere containing $5 \% \mathrm{CO}_{2} / 95 \% \mathrm{O}_{2}$ air in complete medium composed of RPMI 1640 supplemented with $10 \%$ heat-inactivated fetal calf serum, $1 \mathrm{mmol} / 1$ sodium pyruvate, $50 \mu \mathrm{mol} / \mathrm{l}$ 2-mercaptoethanol, $2 \mathrm{mmol} / \mathrm{l}$ glutamine, $25 \mathrm{mmol} / \mathrm{l}$ HEPES, $100 \mathrm{U} / \mathrm{ml}$ penicillin, and $100 \mu \mathrm{g} / \mathrm{ml}$ streptomycin (all from PAA, Switzerland). The maintenance culture was passaged once a week by gentle trypsinization.

\section{Static incubation of attached cells (INS-1, INS-1E)}

The experiments were performed in 12-well plates in $1 \mathrm{ml}$ of medium. Cell density was $3 \times 10^{5}$ per well. Before the experiments, cells were maintained for $2 \mathrm{~h}$ in glucose-free Krebs-Ringer bicarbonate HEPES buffer (KRBH) of the following composition: $135 \mathrm{mmol} / \mathrm{l}$ $\mathrm{NaCl}, 3.6 \mathrm{mmol} / \mathrm{l} \mathrm{KCl}, 5 \mathrm{mmol} / \mathrm{l} \mathrm{NaHCO} 3,0.5 \mathrm{mmol} / \mathrm{l}$ $\mathrm{NaH}_{2} \mathrm{PO}_{4}, 0.5 \mathrm{mmol} / 1 \mathrm{MgCl}_{2}, 1.5 \mathrm{mmol} / \mathrm{l} \mathrm{CaCl}_{2}$, and $10 \mathrm{mmol} / 1 \mathrm{HEPES}, \mathrm{pH}$ 7.4. BSA (0.1\%) was added as an insulin carrier. The cells were then washed twice in PBS and preincubated for $30 \mathrm{~min}$ in glucose-free medium. Next, cells were washed once with glucose-free KRBH and then incubated for $30 \mathrm{~min}$ successively in basal and stimulating media as indicated. Insulin secretion was measured by radioimmunoassay (RIA).

\section{Cell clusters}

INS-1E and INS-1 cells $\left(4 \times 10^{5} / \mathrm{ml}\right)$ were seeded in nonadherent bacterial $10 \mathrm{~cm}$ Petri dishes and cultured in complete medium for 2-3 days before use.

\section{Perifusion of cell clusters}

Spheroid clusters composed of INS-1 or INS-1E cells were preincubated for $2 \mathrm{~h}$ in glucose-free culture medium. After centrifugation $(1000 \mathrm{xg})$, cell clusters were resuspended in glucose-free $\mathrm{KRBH}$ and counted, and about 500 spheroids were distributed per chamber in a $250 \mu \mathrm{l}$ media thermostated at $37{ }^{\circ} \mathrm{C}$. The flow rate of media was set at $0.3 \mathrm{ml} / \mathrm{min}$, and fractions were collected every minute after a $20 \mathrm{~min}$ washing period with $2.5 \mathrm{mmol} / \mathrm{l}$ glucose. Insulin secretion was measured by RIA using rat insulin as a standard.

\section{Incubation media}

Basal medium (292 mOsm/kg $\left.\mathrm{H}_{2} \mathrm{O}\right)$ : KrebsRinger Hepes buffer (KRH) (133,75 mmol/l $\mathrm{NaCl}$, $3.6 \mathrm{mmol} / \mathrm{l} \mathrm{KCl}, 5 \mathrm{mmol} / \mathrm{l} \quad \mathrm{NaHCO}_{3}, \quad 0.5 \mathrm{mmol} / \mathrm{l}$ $\mathrm{NaH}_{2} \mathrm{PO}_{4}, 0.5 \mathrm{mmol} / 1 \mathrm{MgCl}_{2}, 1.5 \mathrm{mmol} / \mathrm{l} \mathrm{CaCl}$, and 10 
mmol/l HEPES, $2.5 \mathrm{mmol} / 1$ glucose, BSA (0.1 \%), pH 7.4 (23).

\section{Stimulating media}

Glucose medium: This medium was prepared by increasing D-glucose concentration to $15 \mathrm{mmol} / \mathrm{l}$. To maintain physiological osmolarity, the $\mathrm{NaCl}$ concentration was reduced to $127.5 \mathrm{mmol} / \mathrm{l}$. Other components were the same as in the basal medium.

Hypotonic medium $\left(202 \mathrm{mOsm} / \mathrm{kg} \mathrm{H}_{2} \mathrm{O}\right): 30 \%$ hypotonic medium was prepared by appropriate dilution of basal medium with deionized water.

Hypertonic medium (352 $\left.\mathrm{mOsm} / \mathrm{kg} \quad \mathrm{H}_{2} \mathrm{O}\right)$ : $60 \mathrm{mmol} / \mathrm{l}$ mannitol was added to glucose medium.

In $\mathrm{Ca}^{2+}$ depleted medium $\mathrm{CaCl}_{2}$ was omitted and $1 \mathrm{mmol} / \mathrm{l}$ EGTA was added.

Specific inhibitors noradrenaline and $\mathrm{GdCl}_{3}$ (Sigma, Germany) were added to stimulating medium in some experiments as indicated.

\section{Confocal laser scanning measurement}

A confocal laser scanning microscope LSM510 META on Axiovert 200 (Zeiss, Germany) was used to investigate proportion parameters of INS-1 and INS-1E cells before and after stimulation by hypotonic medium. All measurements were taken in time series scanning mode using C-Apochromat 40× objective with water immersion (numeric aperture 1.2). He-Ne-laser line (633 nm) was used as an excitation source; emission was detected at 620-680 $\mathrm{nm}$ (BP filter, reflection contrast).

\section{Pancreatic islets}

\section{Isolation of islets of Langerhans}

Islets were isolated from adult male Wistar rats according to the method by Lacy and Kostianovsky (1967). Briefly, under pentobarbital anesthesia (3.7 $\mathrm{mg} / 100 \mathrm{~g}$ body mass) the common bile duct was cannulated proximally near the hilus of the liver, a tie was placed adjacent to the duodenum, and pancreas was distended by injection of approximately $10 \mathrm{ml}$ of Hank's Balanced Salt Solution (HBSS) with $1 \%$ BSA. The pancreas was then dissected out, minced, and digested with $1 \mathrm{mg} / \mathrm{ml}$ collagenase with $0.008 \mathrm{~g}$ soybean Trypsin inhibitor type I-S in $100 \mathrm{ml} \mathrm{HBSS}$ for $10 \mathrm{~min}$ at $37^{\circ} \mathrm{C}$. The tissue was then separated from the remaining acinar tissue under a dissecting microscope and used immediately for the experiment.

\section{Incubation of islets in vitro}

Incubations were performed in Eppendorf tubes at $37{ }^{\circ} \mathrm{C}$. Groups of 5 islets per tube were preincubated for $60 \mathrm{~min}$ in Krebs-Ringer Hepes buffer (KRH) followed by the incubation for two subsequent 30 min periods in basal or stimulating media in final volume of $200 \mu \mathrm{l}$. At the end of each incubation period medium was saved for insulin radioimmunoassay.

\section{Incubation media}

Basal medium: Krebs-Ringer Hepes buffer (KRH) (118 mmol/1 NaCl, $4 \mathrm{mmol} / \mathrm{l} \mathrm{KCl,} 1.2 \mathrm{mmol} / \mathrm{l}$ $\mathrm{MgSO}_{4}, 1.2 \mathrm{mmol} / \mathrm{l} \quad \mathrm{KH}_{2} \mathrm{PO}_{4}, 5 \mathrm{mmol} / \mathrm{l} \quad \mathrm{NaHCO}_{3}$, $25 \mathrm{mmol} / 1 \mathrm{HEPES}, 3 \mathrm{mmol} / 1 \mathrm{D}$-glucose, $2.5 \mathrm{mmol} / \mathrm{l}$ $\mathrm{CaCl}_{2}, 0.1$ \% BSA, pH 7.4 (Bačová et al,. 2005). This medium was used for preincubation and non-stimulated incubation periods.

\section{Stimulating media}

Glucose medium: This medium was prepared by increasing D-glucose concentration to $20 \mathrm{mmol} / \mathrm{l}$. To maintain physiological osmolarity, the $\mathrm{NaCl}$ concentration was reduced to $109.5 \mathrm{mmol} / \mathrm{l}$. Other components were the same as in the basal medium.

Hypotonic medium: $30 \%$ hypotonic medium (202 $\mathrm{mOsm} / \mathrm{kg} \mathrm{H}_{2} \mathrm{O}$ ) was prepared by appropriate dilution of basal medium with deionized water.

Hypertonic medium: $60 \mathrm{mmol} / 1$ mannitol was added to basal medium.

Glucose/hypertonic medium: $\quad 60 \mathrm{mmol} / \mathrm{l}$ mannitol was added to glucose medium.

Specific inhibitors noradrenaline and $\mathrm{GdCl}_{3}$ (Sigma, Germany) were added to stimulating medium.

All media were gassed with $5 \% \mathrm{CO}_{2} / 95 \% \mathrm{O}_{2}$ atmosphere for $30 \mathrm{~min}$ and $\mathrm{pH}$ was 7.4 .

\section{Radioimmunoassay for insulin}

Insulin released into medium was determined directly by specific radioimmunoassay. All samples from each experiment were analyzed in the same assay to avoid interassay variation. Rat insulin standards were prepared in each type of medium we utilized and thus the correction for potential effect of different media on the antibody binding was included.

${ }^{125}$ I-monoiodoinsulin was prepared with the aid of lactoperoxidase (Zorad et al. 1985). Rabbit anti-insulin antibody was provided by Dr. Štolba (Institute of Endocrinology, Prague). Synthetic insulin was obtained from Novo Nordisk (USA). All assays were performed in 
total volume of $400 \mu 10.01 \mathrm{~mol} / \mathrm{l} \mathrm{PBS}$ (pH 7.4). After overnight incubation of samples with the antibody at $4{ }^{\circ} \mathrm{C}$, bound and free peptides were separated by cold $200 \mu 1$ dextran-coated charcoal (500 mg Norit $+50 \mathrm{mg}$ dextran in $100 \mathrm{ml} \mathrm{H} \mathrm{H}_{2} \mathrm{O}$ ). After $15 \mathrm{~min}$ centrifugation at $3000 \mathrm{xg}$, the radioactivity of pellet was measured by RIA multidetector counter (JNG-402, URVJT, Prague).

\section{Data analysis}

Results of static incubations are shown as percentage of basal secretion (mean \pm S.E.). Data from the same samples before and after stimulation were compared by paired Student's t-test. Data from different experiments were evaluated by unpaired $t$-test. Differences were considered significant at level $\mathrm{p}<0.05$.

\section{Results}

A high concentration of extracellular glucose induced distinct insulin release from pancreatic islets and both tumor cell lines by 5 times and 2 times, respectively, showing that all three cell types respond normally to glucose stimulation (Fig. 1A).

Hypotonic medium ( $30 \%$ diluted basal medium) increased insulin secretion from pancreatic islets by 4 times and from INS-1 cells by 5 times (Fig. 1B). In contrast, INS-1E cells responded to hypotonic medium by a $50 \%$ decrease in insulin secretion. The same results were obtained when hypotonicity was achieved by reducing of $\mathrm{NaCl}$ concentration to $55 \mathrm{mM}$ (data not shown). The absence of secretory response to hypotonicity in INS-1E cells prompted us to measure changes of cell volume after osmotic stimulus. Direct measurements of cell size showed a significant increase in 2D cell area by 9 and $13.1 \%$ of INS-1E and INS-1 cells, respectively, in hypotonic medium (Table 1) indicating cell swelling. The width (shorter parameter) increased more than the length in both cell lines suggesting their shape was more rounded after swelling. Although measured parameters were larger in INS-1E than in INS-1 cells, there was no significant difference between the changes of $2 \mathrm{D}$ area (\%) suggesting similar responsiveness of both cell lines to osmotic challenge.

To explain the inability of hypotonic medium to induce insulin secretion from INS-1E cells, we examined the role of stretch-sensitive channels in these effects. A presence of $100 \mu \mathrm{mol} / 1 \mathrm{GdCl}_{3}$, an inhibitor of stretch sensitive channels, in the medium did not affect basal or hypotonicity-induced insulin secretion from INS-1E cells
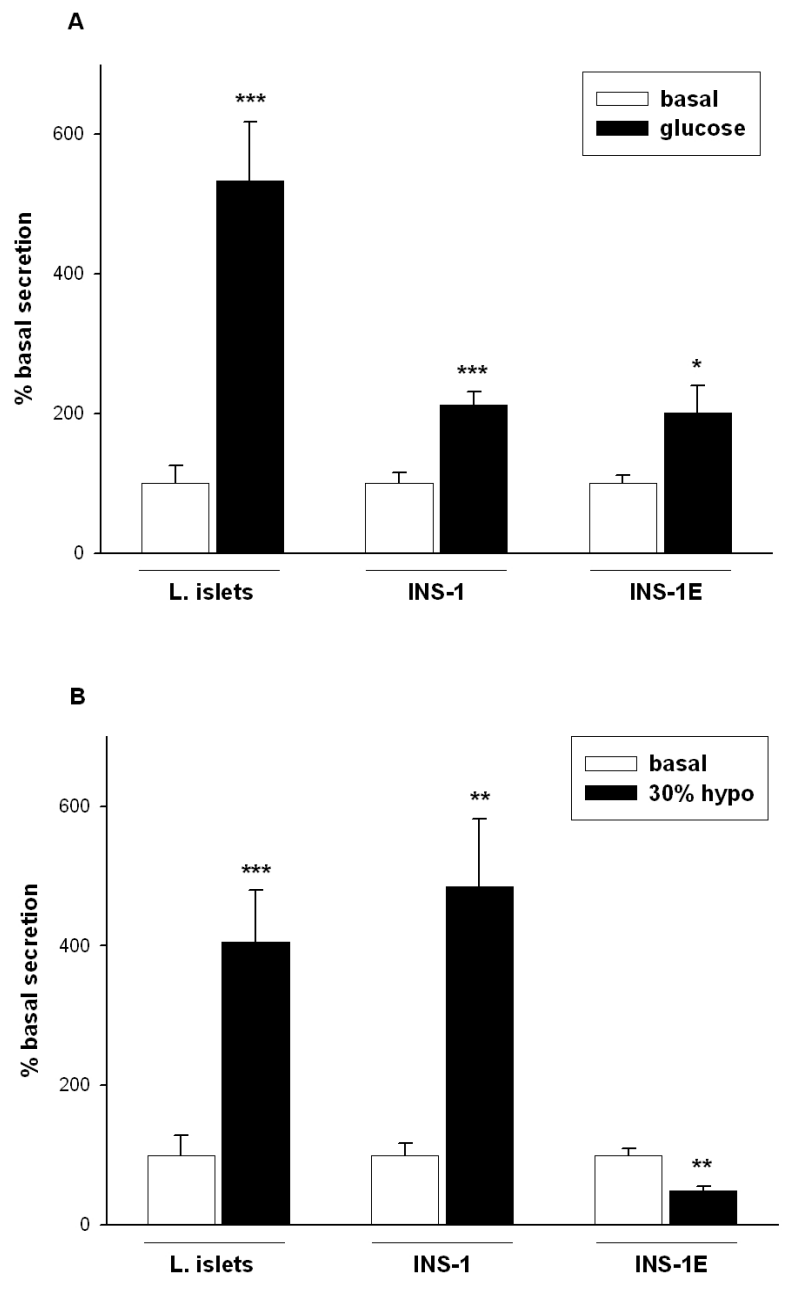

Fig. 1. Insulin secretion in response to glucose and $30 \%$ hypotonic medium (hypo) from isolated Langerhans's islets and cell lines (INS-1, INS-1E). After preincubation islets ( 5 per tube) or cells were incubated for two subsequent 30 min periods in control (basal) medium and stimulating medium A: high glucose medium; B: $30 \%$ hypotonic medium (detailed composition see in Material and Methods). Insulin secretion under basal conditions was considered to be $100 \%$. Values are mean \pm S.E. $(n=10)$; * $\mathrm{P}<0.05 ; * * \mathrm{P}<0.005 ; * * * \mathrm{P}<0.001$ compared to previous control period. All three systems released insulin in response to glucose challenge. INS-1E cells do not release insulin in response to hypotonicity.

(Fig. 2) suggesting that these channels do not play a significant role in the mechanism of insulin secretion.

The atypical secretory reaction to hypotonic stimulus in INS-1E cells suggested irregular response of these cells to osmotic and/or cell volume changes. Therefore, we tested the effects of hypertonic stimulus on insulin secretion. As expected, in pancreatic islets, the glucose-induced insulin secretion was prevented by the hypertonic medium (Fig. 3). However, in both tumor cell lines, the hypertonicity did not have any effect on glucose-induced insulin secretion further underlying differences between normal and tumor cells. 
Table 1. Volume changes of INS-1E and INS-1 cells after hypotonic stimulation.

\begin{tabular}{|c|c|c|c|c|c|c|c|c|c|c|}
\hline & \multirow[b]{2}{*}{$\mathbf{n}$} & \multicolumn{3}{|c|}{ Width } & \multicolumn{3}{|c|}{ Length } & \multicolumn{3}{|c|}{ Area } \\
\hline & & $\begin{array}{c}\text { Before } \\
(\mu \mathrm{m})\end{array}$ & $\begin{array}{l}\text { After } \\
(\mu \mathrm{m})\end{array}$ & $\begin{array}{c}\text { Changes } \\
(\%)\end{array}$ & $\begin{array}{c}\text { Before } \\
(\mu \mathrm{m})\end{array}$ & $\begin{array}{c}\text { After } \\
(\mu \mathrm{m})\end{array}$ & $\begin{array}{c}\text { Changes } \\
(\%)\end{array}$ & $\begin{array}{c}\text { Before } \\
\left(\mu \mathbf{m}^{2}\right)\end{array}$ & $\begin{array}{l}\text { After } \\
\left(\mu \mathbf{m}^{2}\right)\end{array}$ & $\begin{array}{c}\text { Changes } \\
(\%)\end{array}$ \\
\hline \multirow{2}{*}{ INS-1 } & \multirow{2}{*}{7} & 14.5 & 16.1 & 10.3 & 32.2 & 38.9 & 2.7 & 345.6 & 387 & 13.1 \\
\hline & & \pm 1.3 & $\pm 1.5^{* * *}$ & \pm 0.9 & \pm 4.9 & $\pm 4.8^{* *}$ & \pm 0.9 & \pm 51.1 & $\pm 54.8^{* * *}$ & \pm 2.1 \\
\hline \multirow{2}{*}{$I N S-1 E$} & \multirow{2}{*}{4} & 21.1 & 22.6 & 7.51 & 41.1 & 44.6 & 3.5 & 632.5 & 687 & 9.0 \\
\hline & & \pm 2 & \pm 2 & \pm 2.50 & \pm 2.6 & $\pm 2.5^{*}$ & \pm 0.7 & \pm 50.5 & $\pm 45.7^{*}$ & \pm 2.83 \\
\hline
\end{tabular}

Measurements were taken in time series scanning mode using a confocal laser-scanning microscope. Parameters were measured before and $90 \mathrm{~s}$ after hypotonic stimulation. Values are shown as mean $\pm \mathrm{S}$.E. $* \mathrm{P}<0.05, * * \mathrm{P}<0.005, * * * \mathrm{P}<0.001$, compared to parameters before stimulation (paired t-test).

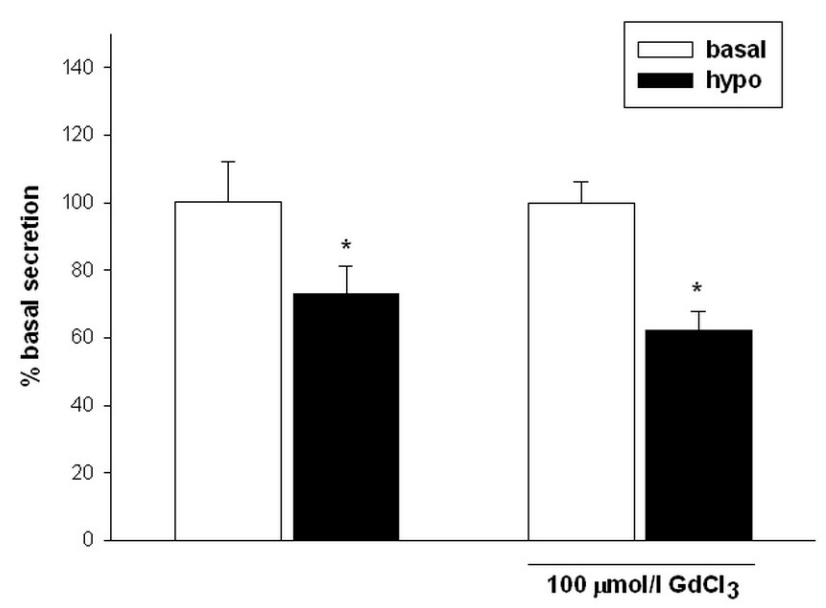

Fig. 2. Effect of $\mathrm{GdCl}_{3}$, an inhibitor of stretch-sensitive channels, on insulin secretory response to hypotonic medium in INS-1E cells. After preincubation the cells were incubated in basal KRBH and then in $30 \%$ hypotonic medium (hypo) with or without 100 $\mu \mathrm{mol} / \mathrm{l} \mathrm{GdCl}$ over 30 min periods. Insulin secretion during control period was considered to be $100 \%$. Values are shown as mean \pm S.E. $(n=10) ; * P<0.05$ compared to previous control period. $\mathrm{GdCl}_{3}$ did not affect basal and hypotonicity-induced secretion.

Noradrenaline, a physiological inhibitor of insulin release, prevented glucose-induced insulin secretion (Fig. 4A) from INS-1 cells; however, it did not prevent the swelling-stimulated insulin secretion (Fig. 4B). The response of INS-1E cells to both stimuli was not compared because of the absence of the response to swelling under the conditions necessary for glucose stimulation ( $\mathrm{Ca}^{2+}$ containing medium).

It was not possible to test the responses of tumor cell lines in $\mathrm{Ca}^{2+}$-depleted medium in static incubations as described above because the cells do not adhere to the surface of plates under these conditions. Therefore the experiments with perifusion of cell clusters were used. Typical result from repeated experiments is shown in Figure 5. Perifusion confirmed inability of INS-1E cells to release insulin in response to hypotonicity in the presence of extracellular $\mathrm{Ca}^{2+}$ (Fig. 5A). Surprisingly, distinct insulin release appeared during perifusion of INS$1 \mathrm{E}$ cells with $\mathrm{Ca}^{2+}$-depleted hypotonic medium (Fig. 5B); this response was even higher than that seen in INS-1 cells in which the release was partially inhibited.

\section{Discussion}

Clonal INS-1E cells were isolated from parental INS-1 based on insulin content and secretory response to glucose (Merglen et al. 2004). INS-1E cell line has been provided to many investigators including our laboratory. We have taken an advantage of having two insulin secreting cell lines responsive to glucose and have compared their secretory properties in response to osmotic stimuli with freshly isolated pancreatic islets.

All three in vitro models e.g. isolated pancreatic islets and both tumor cell lines released insulin in response to glucose challenge, demonstrating a functional glucose-activated signal transduction pathway. Hypotonic medium containing $\mathrm{Ca}^{2+}$ induced insulin secretion from the pancreatic islets and INS-1 cells, whereas insulin secretion was inhibited from INS-1E cells. A difference between insulin response to glucose and hypotonicity in this cell line indicates that a complete signaling activated by glucose stimulation is not a sufficient prerequisite for secretory response to cell swelling suggesting that some extra step(s) is required to trigger swelling-induced exocytosis.

Direct measurements of cell size showed that hypotonic medium induced swelling of both INS-1 and INS-1E cells. Miley et al. (1997) reported that both glucose and hypotonic medium induced swelling of $\beta$ cells. Recently, Jakab et al. (2006) have shown that both 
A

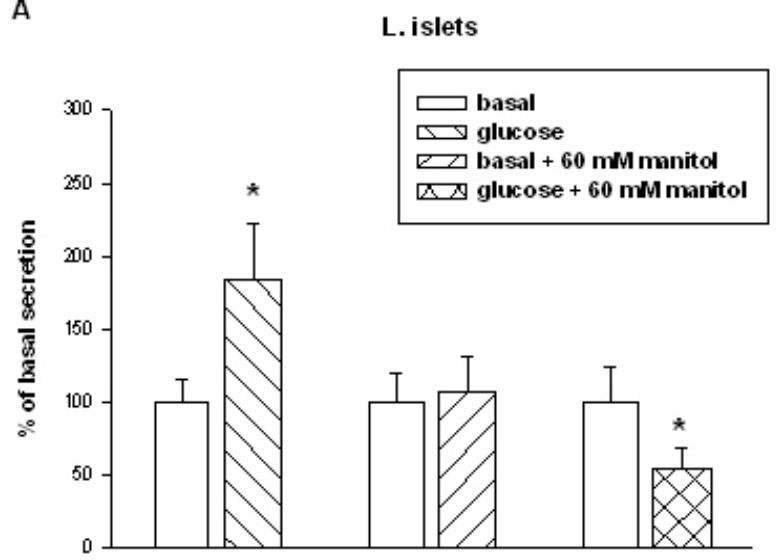

B

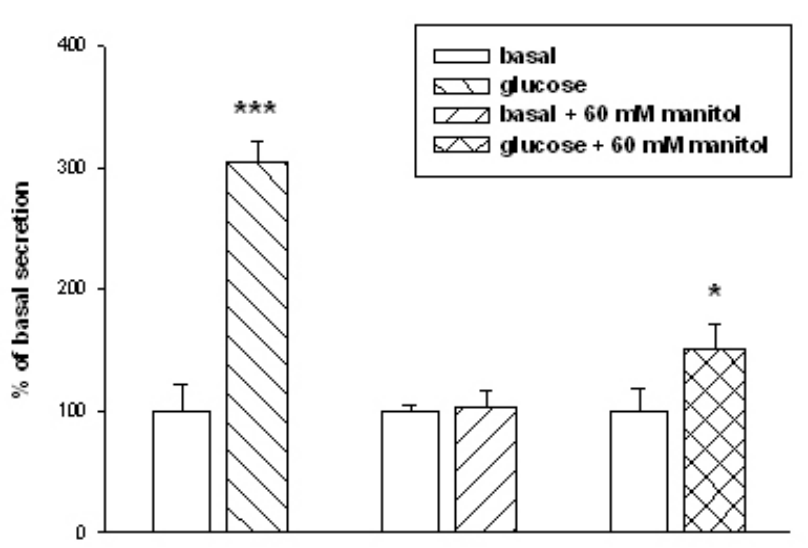

C

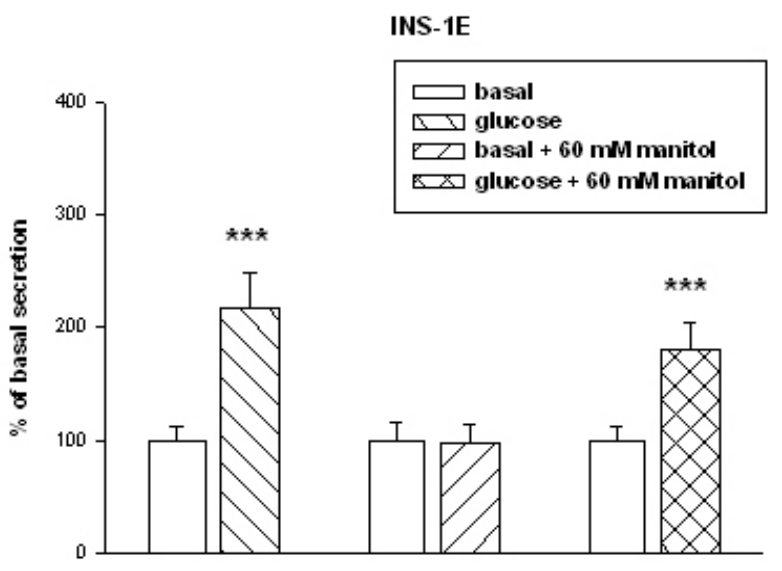

Fig. 3. Insulin secretion in response to hypertonic medium from isolated Langerhans's islets and INS-1, INS-1E cell lines. After preincubation, islets ( 5 per tube) or cells were incubated for two subsequent $30 \mathrm{~min}$ periods in control (basal) medium and stimulating (glucose medium, hypertonic medium and glucose/hypertonic medium (see Material and Methods)). Insulin secretion under basal condition was considered to be $100 \%$. Values are shown as mean \pm S.E. $(\mathrm{n}=10) ; * \mathrm{P}<0.05 ; * * * \mathrm{P}<0.001$ compared to previous control period. Hypertonicity of medium inhibited stimulating effect of glucose in islets (A) but not in pancreatic cell lines (B: INS-1; C: INS-1E). high glucose and hypotonicity induced swelling in INS$1 \mathrm{E}$ cells and superfusion with an isotonic solution containing $20 \mathrm{mmol} / \mathrm{l}$ glucose or a $30 \%$ hypotonic solution led to the activation of chloride conductance. These studies have implied that swelling of ß-cells may be an integral part of glucose-activated signaling inducing insulin secretion. However, our present data showing that INS-1E cells in the presence of extracellular $\mathrm{Ca}^{2+}$ have a normal secretory response to glucose but are unable to release insulin in response to hypotonicity suggest that cell swelling-induced exocytosis is not an essential step in glucose-induced stimulation of insulin release. However, the possibility that swelling is involved in signal transduction of glucose-induced insulin secretion by inducing other mechanism(s) not comprising exocytosis remains possible.

A failure to identify transduction pathway of cell swelling-induced exocytosis and its resistance to physiological inhibitors like noradrenaline suggests that this signaling pathway bypasses conventional transduction steps and/or may be effective at the distal end of the cascade. It has been shown that swelling of secretory vesicles is critical step of exocytosis (Finkelstein et al. 1986, Alvarez de Toledo et al. 1993, Lin et al. 1996, Tsuboi et al. 2002). Stretching of vesicular and plasma membranes in the region of contact results in exposure of hydrophobic acyl chains leading to subsequent merging and fusion. The fusion rates are order of magnitude higher if an osmotic gradient across plasma membrane is present (Finkelstein et al. 1986). The externalization of hormones or neurotransmitters upon exocytosis of vesicles is augmented by water efflux from the vesicle membrane through the widened fusion pore (Tsuboi et al. 2002). Based on these data, we had hypothesized that exocytosis triggered by cell swelling is a result of direct biophysical effect of the osmotic gradient on secretory vesicles (Štrbák et al. 2004). However, our present data demonstrating that rat INS-1E tumor $\beta$ cells swelling in response either to glucose or hypotonicity (Jakab et al. 2006) are unable to release insulin in response to cell swelling despite a good response to glucose, challenge this hypothesis. It is well documented that swelling of secretory vesicles precedes exocytosis (Pow and Morris 1989, Hattori et al. 1990, Landgraf et al. 1990, Landgraf and Ludwig 1991). Therefore, if the vesicle swelling alone was the only essential prerequisite of hypotonicity induced exocytosis, it is unlikely that secretory vesicles with normal response to glucose stimulation would not release insulin in response to cell swelling. 
A

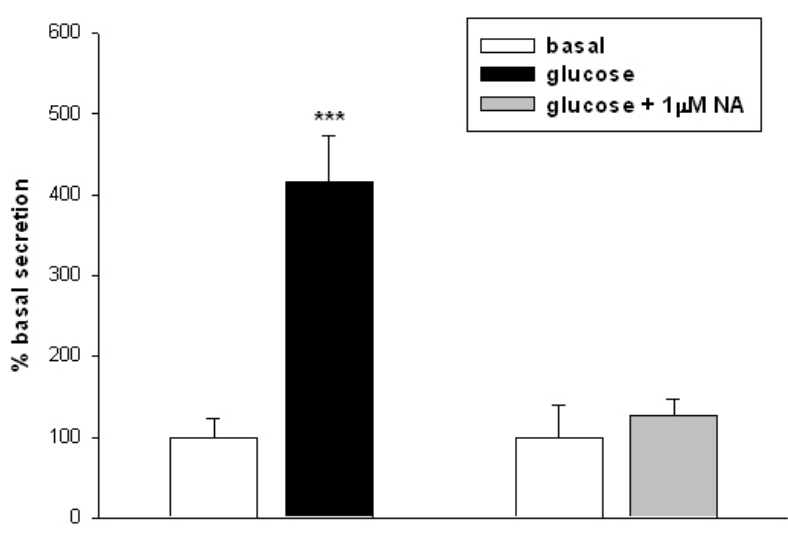

B

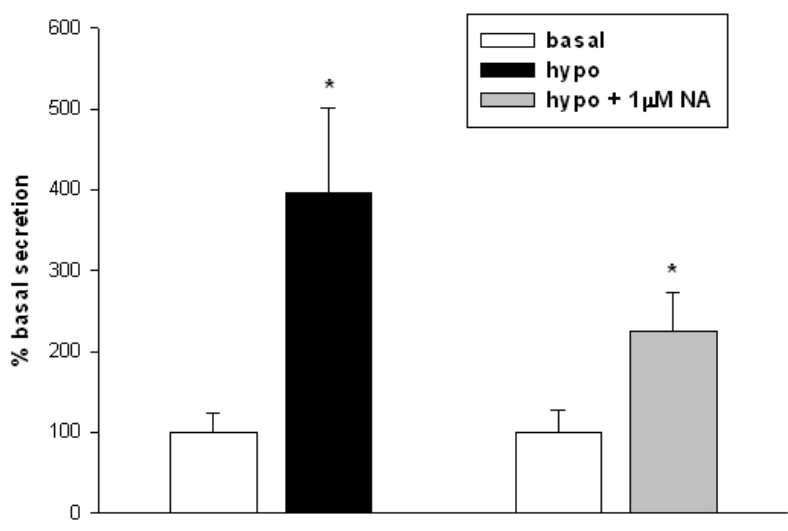

Fig. 4. Effect of physiological inhibitor noradrenaline (NA) on stimulated insulin secretion from INS-1cell line. After preincubation the cells were incubated for two subsequent 30 min periods in control (basal) medium and stimulating medium. A: glucose medium; B: hypotonic medium (see Material and Methods) with or without $1 \mu \mathrm{mol} / \mathrm{I}$ NA. Insulin secretion during control period was considered to be $100 \%$. Values are shown as mean \pm S.E. $(\mathrm{n}=10) ; * \mathrm{P}<0.05 ; * * * \mathrm{P}<0.001$ compared to control period. Stimulating effect of glucose but not that of hypotonicity was prevented by NA.

It is possible that INS-1E cells either do not adequately perceive the change of cell volume or they react specifically to osmotic stimuli as it has been shown for oxytocin (OT) and vasopressin secreting cells. Direct stimulation of the hypothalamic paraventricular (PVN) or supraoptic nucleus (SON) with hypertonic saline increases vasopressin and OT secretion (Pow and Morris 1989, Hattori et al. 1990, Landgraf et al. 1990, Landgraf and Ludwig 1991, Hattori et al. 1992). It has been also shown that hypotonic stimuli hyperpolarize magnocellular neurosecretory cells via stretch-inactivated channels (Bourgue and Oliet 1997). In our previous studies (Najvirtová et al. 2002, Bačová et al. 2006b), we used tissue explants of hypothalamic PVN and posterior pituitary for simultaneous thyrotropin releasing hormone
(TRH) and OT examination. While TRH secretion was stimulated by cell swelling, OT, a neurohormone engaged in water and salt regulation, was not released after cell swelling-inducing stimuli (Najvirtová et al. 2003). We have shown (Bačová et al. 2006b) that an unspecific intranuclear OT response to hypotonic stimulation (e.g. hypotonicity stimulated OT release) within the PVN and the SON could be unmasked by inhibiting the specific response in the presence of 50 or $100 \mu \mathrm{mol} / 1 \mathrm{GdCl}_{3}$, an inhibitor of stretch-sensitive channels (Yang and Sachs 1989, Oliet and Bourgue 1996) and a potent blocker of voltage-sensitive $\mathrm{Ca}^{2+}$ channels (Romano-Silva et al. 1994). INS-1E cells responded to hypotonic stimulation by decreased insulin secretion suggesting a possibility of stretch sensitive channels mediated specific response to osmotic stimulus. Hypotonic medium did not induce, however, insulin release even in presence of $100 \mu \mathrm{mol} / \mathrm{l}$ $\mathrm{GdCl}_{3}$. These results suggest that the $\mathrm{GdCl}_{3}$-sensitive mechanisms (involving mechanoreceptors regulated channels and/or voltage-gated $\mathrm{Ca}^{2+}$ channels) are not responsible for atypical secretory behavior of INS-1E cells in hypotonic medium. However, possibility that mechanosensitive receptors and their sensitivity are comprised in this tumor cell line although, unlikely, can not be excluded.

We conclude that swelling-induced insulin secretion requires extra step(s) which does not occur in signaling of glucose-induced insulin secretion and is not active in INS-1E cells in presence of extracellular $\mathrm{Ca}^{2+}$. However, specific response of neuropeptides within hypothalamic nuclei involves $\mathrm{Ca}^{2+-}$ dependent mechanisms (Hattori et al. 1990, Ludwig and Landgraf 1992, Bačová et al. 2006b). When $\mathrm{GdCl}_{3}$ was used, EGTA was omitted to prevent chelator neutralization in our experiments. In perifusion experiments $\mathrm{Ca}^{2+}$ depletion was more complete (both $\mathrm{CaCl}_{2}$ omission and EGTA added to medium). It can be speculated that a specific response insensitive to $\mathrm{GdCl}_{3}$ and requiring $\mathrm{Ca}^{2+}$ was involved in the mechanism of inhibiting effect of hypotonicity on insulin secretion in INS-1E cells. However, hypothalamic magnocellular neurons increase cell size in response to hyperosmolar conditions and decrease cell size in response to hyposmolar conditions (Zhang et al. 2001) and hypotonic stimuli hyperpolarize magnocellular neurosecretory cells via stretch-inactivated channels (Bourque and Oliet 1997). In contrast, INS-1E cells swelled in response to hypotonic medium in our experiments. Although we can not exclude a specific reaction, we consider this possibility unlikely. 
A

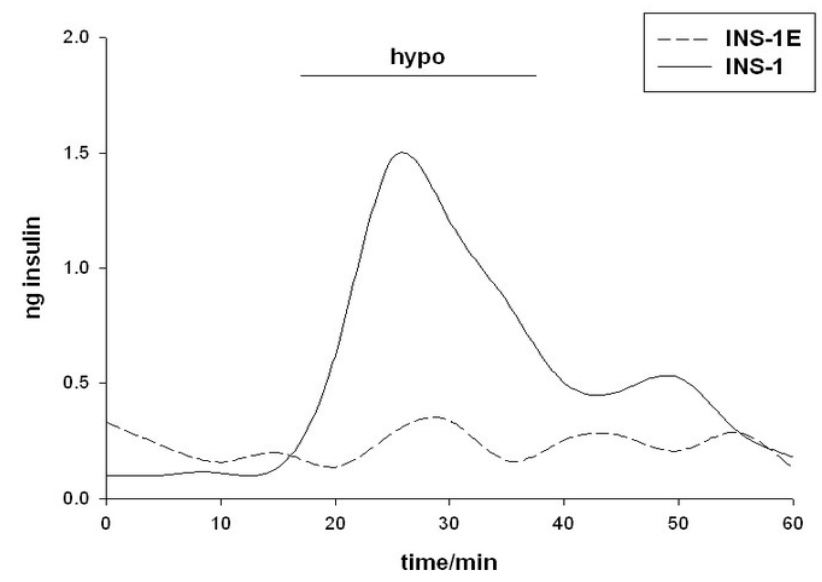

B

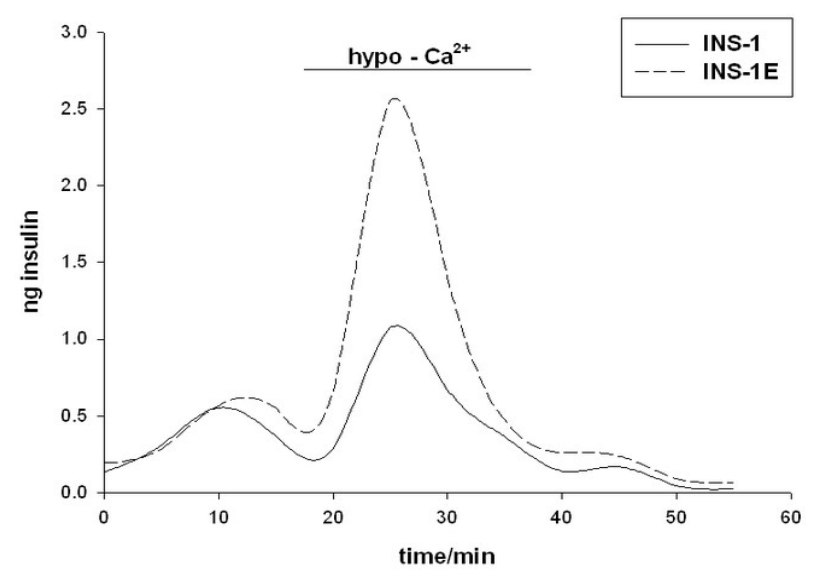

Fig. 5. Secretory responses of spheroid clusters composed of INS-1E and INS-1 cells. Typical results of repeated experiments are shown. Clusters of INS-1E and INS-1 cells were perifused at flow rate $0.3 \mathrm{ml} / \mathrm{min}$ with basal medium containing $2.5 \mathrm{mmol} / \mathrm{l}$ glucose (20 min) and stimulating $30 \%$ hypotonic medium (30\% hypo, $20 \mathrm{~min}), \mathbf{A}$ : in presence of $1.5 \mathrm{mmol} / \mathrm{CaCl}_{2} ; \mathbf{B}$ : in $\mathrm{Ca}^{2+}$ depleted medium containing $1 \mathrm{mmol} / \mathrm{I}$ EGTA. $\mathrm{Ca}^{2+}$ containing hypotonic medium induced insulin secretion only in INS-1 cells. In $\mathrm{Ca}^{2+}$ depleted medium hypotonicity induced burst of insulin secretion in INS-1E cells which was even higher than partially inhibited response of INS-1 cells.

Negative modulation of osmotically induced secretion by $\mathrm{Ca}^{2+}$ influx was found in many types of secretory cells (for review Štrbák and Greer 2000) and is most likely related to effective regulatory volume decrease. When medium $\mathrm{Ca}^{2+}$ is depleted or $\mathrm{Ca}^{2+}$ influx prevented by $\mathrm{Ca}^{2+}$ channel blockers, the amplitude of cell swelling is greater and the regulatory volume decrease (RVD) slower. The apparent negative modulation of osmotically induced secretion by $\mathrm{Ca}^{2+}$ influx in normal pituitary cells may simply be due to an augmented signal intensity resulting from the greater magnitude and duration of cell swelling from an osmotic stimulus when $\mathrm{Ca}^{2+}$ influx is prevented than when it occurs (Štrbák and Greer 2000).
It could be speculated that bigger INS-1E cells are less sensitive to volume changes and perceive only more profound change in absence of $\mathrm{Ca}^{2+}$. If this was a true, secretory response of INS-1E cells to swelling would be smaller but not inhibited as in our case. The mechanism and role of $\mathrm{Ca}^{2+}$ in swelling-induced insulin secretion of INS-1E cells remains therefore to be clarified.

The opposite osmotic manipulation inducing cell shrinking has most often suppressing effect on peptide/ protein secretory response (for review see Štrbák and Greer 2000, Štrbák 2006). Therefore, we tested whether stimulating effect of glucose on insulin secretion can be affected by hypertonic medium. As expected, hypertonicity inhibited response of pancreatic islets to glucose stimulation. In contrast, both tumor cell lines responded with distinct release of insulin. A similar effect was observed in HIT-T 15 cells which released insulin in response to hypertonic glucose, although the response was decreased as compared to isotonic conditions (Sato et al. 1996). These data suggest different sensing and/or sensitivity to the effects of osmolarity in insulin secreting tumor cell lines compared to pancreatic islets.

We have shown in previous study that noradrenaline, a physiological inhibitor of insulin secretion, fully abolished glucose-induced insulin secretion from isolated pancreatic islets but did not inhibit hypotonic stimulation (Bačová et al. 2005). Since INS-1 cells, in contrast to INS-1E, release insulin in response to hypotonicity in the presence of extracellular $\mathrm{Ca}^{2+}$, we examined the effect of noradrenaline on both glucose and hypotonicity stimuli of insulin secretion. We found similar response to that observed in freshly isolated pancreatic islets; the secretory response of INS-1 cells to glucose but not that to hypotonicity was inhibited by noradrenaline.

In term of insulin secretory response, INS-1E cells react atypically to cell swelling-inducing stimulus despite a good response to glucose. Both INS-1 and INS$1 \mathrm{E}$ cell lines were found to be resistant or at least less sensitive to the inhibitory effect of hypertonicity. The mechanism by which an increase or a decrease in cell volume are sensed and subsequently transduced into activation of cell volume sensitive mechanisms is subject of intense studies (Hoffmann et al. 2006). In higher eukaryotes, the available evidence indicates that there are probably multiple mechanisms by which volume changes are initially sensed (Hoffmann et al. 2006). However, those related to a swelling-induced peptide secretion 
remain unknown. We have found that there are alternative signaling pathways for hypotonicity-induced insulin secretion in these INS cell lines; one of them was inactivated by the presence of extracellular $\mathrm{Ca}^{2+}$. Interestingly, Straub et al. (2002) suggested two different mechanisms leading to swelling-induced exocytosis in the presence and absence of $\mathrm{Ca}^{2+}$ in the medium in insulin secreting $\beta \mathrm{HC} 9$ cells. Similar phenomenon (e.g. $\mathrm{Ca}^{2+}$ dependence) was described previously in tumor-derived rat pituitary cells (Sato et al. 1991). This may be a specific property of some tumor cell lines; swellinginduced insulin secretion in natural cells is independent from either extracellular or intracellular $\mathrm{Ca}^{2+}$, i.e. is active either in the presence or absence of extracellular $\mathrm{Ca}^{2+}$ (Štrbák and Greer 2000, Bačová et al. 2005, Štrbák 2006). Further analysis of mechanism by which $\mathrm{Ca}^{2+}$ inhibits swelling-induced insulin secretion in INS-1E cells may provide an effective tool to unravel signal transduction pathway(s) of swelling-induced peptide secretion.

In conclusion, a functional glucose-activated signal transduction pathway is not a sufficient prerequisite for swelling-induced insulin release, thus demonstrating the necessity of extra signaling step(s) mediating responses to osmotic effects. Swelling-induced exocytosis is not an essential step in glucose-induced signaling mediating insulin secretion. The paradoxical response of INS-1E cells to swelling in the presence of extracellular $\mathrm{Ca}^{2+}$ is not mediated by $\mathrm{GdCl}_{3}$ (stretch)sensitive channels. Both, INS-1 and INS-1E cell lines are resistant to the inhibitory effects of hypertonicity on glucose-induced insulin secretion. The depletion of $\mathrm{Ca}^{2+}$ from medium had permissive effects on hypotonicityinduced insulin secretion from INS-1E cells. Further studies of these cell lines may provide an important insight into mechanisms of cell swelling-induced peptide secretion.

\section{Conflict of Interest}

There is no conflict of interest.

\section{Acknowledgements}

The work was supported by the project 2/6158/26 of the Grant Agency of Ministry of Education and Slovak Academy of Sciences (VEGA), project APVV 0235-06, VVCE-0064-07 and project of CE SAV CENDO. Authors thank to Dr. Claes B. Wollheim and Pierre Maechler (University Medical Center, Geneva) for providing kind gift of INS-1 ans INS-1E rat insulin secreting cell lines and to Institute of Endocrinology (Prague) for providing us with specific rabbit anti-rat insulin antibody prepared by Dr. Pavel Štolba.

\section{References}

ALVAREZ DE TOLEDO G, FERNANDEZ-CHACON R, FERNANDZ JM: Release of secretory products during transient vesicle fusion. Nature 363: 554-558, 1993.

BAČOVÁ, Z, BENICKY J, LUKYANETZ EE, LUKYANETZ IA, ŠTRBÁK V: Different signaling pathways involved in glucose- and cell swelling-induced insulin secretion by rat pancreatic islets in vitro. Cell Physiol Biochem 16: 59-68, 2005.

BAČOVÁ Z, BAQI L, BENAČKA O, PAYER J, KRIŽANOVÁ O, ZEMAN M, SMREKOVÁ L, ZÓRAD S, ŠTRBÁK V: Thyrotropin releasing hormone in rat heart: effect of swelling, angiotensin II and renin gene. Acta Physiol Oxf 187: 313-319, 2006a.

BAČOVÁ, Z, KISS A, JAMAL B, PAYER J JR, ŠTRBÁK V: The effect of swelling on TRH and oxytocin secretion from hypothalamic structures. Cell Mol Neurobiol 26: 1047-1055, $2006 \mathrm{~b}$.

BAČOVÁ Z, OREČNA M, HAFKO R, ŠTRBÁK V: Cell swelling-induced signaling for insulin secretion bypasses steps involving $\mathrm{G}$ proteins and $\mathrm{PLA}_{2}$ and is N-ethylmaleimide insensitive. Cell Physiol Biochem 20: 387-396, 2007.

BLACKARD WG, KIKUCHI M, RABINOVITCH A, RENOLD AE: An effect of hyposmolarity on insulin release in vitro. Am J Physiol 228: 706-713, 1975.

BOURQUE CW, OLIET SHR: Osmoreceptors in the central nervous system. Annu Rev Physiol 59: 601-619, 1997.

FINKELSTEIN A, ZIMMERBERG J, COHEN FS: Osmotic swelling of vesicles: its role in the fusion of vesicles with planar phospholipid bilayer membranes and its possible role in exocytosis. Annu Rev Physiol 48: 163-174, 1986. 
GREER MA, GREER SE, OPSAHL Z, MARUTA S: Comparison of hyposmolar and hyperosmolar effects on in vitro luteinizing hormone secretion by anterior pituitary cells. Proc Soc Exp Biol Med 178: 24-28, 1985.

GREER MA, GREER SE, OPSAHL Z, MCCAFFERTY L, MARUTA S: Hyposmolar stimulation of in vitro pituitary secretion of luteinizing hormone: a potential clue to the secretory process. Endocrinology 113: 1531-1533, 1983.

HATTORI T, MORRIS M, ALEXANDER N, SUNDBERG DK: Extracellular oxytocin in the paraventricular nucleus: hyperosmotic stimulation by in vivo microdialysis. Brain Res 506: 169-171, 1990.

HATTORI T, SUNDBERG DK, MORRIS M: Central and systemic oxytocin release: a study of the paraventricular nucleus by in vivo microdialysis. Brain Res Bull 28: 257-263, 1992.

HOFFMANN EK, LAMBERT IH, PEDERSEN SF: Editorial. Acta Physiol Oxf 187: 1-3, 2006.

JAKAB M, FURST J, GSCHWENTNER M, BOTTA G, GARAVAGLIA ML, BAZZINI C, RODIGHIERO S, MEYER G, EICHMUELLER S, WOLL E, CHWATAL S, RITTER M, PAULMICHL M: Mechanisms sensing and modulating signals arising from cell swelling. Cell Physiol Biochem 12: 235-258, 2002.

JAKAB M, GRUNDBICHLER M, BENICKY J, RAVASIO A, CHWATAL S, SCHMIDT S, STRBAK V, FURST J, PAULMICHL M, RITTER M: Glucose induces anion conductance and cytosol-to-membrane transposition of ICln in INS-1E rat insulinoma cells. Cell Physiol Biochem 18: 21-34, 2006.

KUCEROVA J, ŠTRBÁK V: The osmotic component of ethanol and urea action is critical for their immediate stimulation of thyrotropin-releasing hormone (TRH) release from rat brain septum. Physiol Res 50: 309-314, 2001.

LACY PE, KOSTIANOVSKY M: Method for the isolation of intact islets of Langerhans from the rat pancreas. Diabetes 16: 35-39, 1967.

LANDGRAF R, LUDWIG M: Vasopressin release within the supraoptic and paraventricular nuclei of the rat brain: osmotic stimulation via microdialysis. Brain Res 558: 191-196, 1991.

LANDGRAF R, MALKINSON T, HORN T, VEALE WL, LEDERIS K, PITTMAN QJ: Release of vasopressin and oxytocin by paraventricular stimulation in rats. Am J Physiol 258: R155-R159, 1990.

LANG F, BUSCH GL, RITTER M, VOLKL H, WALDEGGER S, GULBINS E, HAUSSINGER D: Functional significance of cell volume regulatory mechanisms. Physiol Rev 78: 247-306, 1998a.

LANG F, BUSCH GL, VOELKL H: The diversity of volume regulatory mechanisms. Cell Physiol Biochem 8: 1-45, 1998b.

LIM SK, KWON YH, SONG YD, LEE HC, RYU KJ, HUH KB, PARK CS: Swelling of the vesicle is prerequisite for PTH secretion. Yonsei Med J 37: 59-67, 1996.

LUDWIG M, LANDGRAF R: Does the release of vasopressin within the supraoptic nucleus of the rat brain depend upon changes in osmolality and $\mathrm{Ca}^{2+} / \mathrm{K}^{+}$? Brain Res 576: 231-234, 1992.

MERGLEN A, THEANDER S, RUBI B, CHAFFARD G, WOLLHEIM CB, MAECHLER P: Glucose sensitivity and metabolism-secretion coupling studied during two-year continuous culture in INS-1E insulinoma cells. Endocrinology 145: 667-678, 2004.

MILEY HE, SHEADER EA, BROWN PD, BEST L: Glucose-induced swelling in rat pancreatic beta-cells. $J$ Physiol 504: 191-198, 1997.

NAJVIRTOVÁ M, BAQI L, KUČEROVÁ J, ŠTRBÁK V: Cell swelling induced secretion of TRH by posterior pituitary, hypothalamic paraventricular nucleus and pancreatic islets: effect of L-canavanine. Cell $\mathrm{Mol}$ Neurobiol 22: 35-46, 2002.

NAJVIRTOVÁ M, GREER SE, GREER MA, BAQI L, BENICKÝ J, ŠTRBÁK V: Cell volume induced hormone secretion: studies on signal transduction and specificity. Cell Physiol Biochem 13: 113-122, 2003.

NIKODÉMOVÁ M, GREER MA, ŠTRBÁK V: Hypo-osmolarity stimulates and high sodium concentration inhibits thyrotropin-releasing hormone secretion from rat hypothalamus. Neuroscience 88: 1299-1306, 1999.

OLIET SHR, BOURQUE CW: Gadolinium uncouples mechanical detection and osmoreceptor potential in supraoptic neurons. Neuron 16: 175-181, 1996.

POW DV, MORRIS JF: Dendrites of hypothalamic magnocellular neurons release neurohypophysial peptides by exocytosis. Neuroscience 32: 435-439, 1989. 
ROMANO-SILVA MA, GOMEZ MV, BRAMMER MJ: The use of gadolinium to investigate the relationship between $\mathrm{Ca}^{2+}$ influx and glutamate release in rat cerebrocortical synaptosomes. Neurosci Lett 178: 155-158, 1994.

SATO N, MURAKAMI M, WANG X, GREER MA: The contrasting role of calcium influx in secretion induced by cell swelling can differentiate normal and tumorderived rat pituitary cells. Endocrinology 129: 2541-2546, 1991.

SATO N, WANG X, GREER MA: Hyposmolarity stimulates exocytosis from human polymorphonuclear leukocytes. Am J Med Sci 289: 309-312, 1990.

SATO N, KASHIMA K, SHIMIZU H, SHIMOMURA Y, MORI M: Hypertonic glucose impairs glucose-induced increases in cytosol $\mathrm{Ca}^{2+}$ concentration and insulin secretion by HIT-T 15 cells. Cell Calcium 20: 273-278, 1996.

STRAUB SG, DANIEL S, SHARP GW: Hyposmotic shock stimulates insulin secretion by two distinct mechanisms. Studies with the BHC9 cell. Am J Physiol 282: E1070-E1076, 2002.

ŠTRBÁK V, BENICKY J, GREER SE, BAČOVÁ Z, NAJVIRTOVÁ M, GREER MA: Cell swelling-induced peptide hormone secretion. In: Cell Volume and Signaling, Adv Exp Med Biol. Vol 559, PK LAUF, NC ADRAGNA (eds), Springer, New York, 2004, pp 325-330.

ŠTRBÁK V, GREER MA: Regulation of hormone secretion by acute cell volume changes: $\mathrm{Ca}^{2+}$-independent hormone secretion. Cell Physiol Biochem 10: 393-402, 2000.

ŠTRBÁK V: Cell volume and peptide hormone secretion. Contrib Nephrol 152: 210-20, 2006.

TSUBOI T, KIKUTA T, SAKURAI T, TERAKAWA S: Water secretion associated with exocytosis in endocrine cells revealed by micro forcemetry and evanescent wave microscopy. Biophys $J$ 83: 173-182, 2002.

WANG X, SATO N, GREER MA: Medium hyperosmolarity inhibits prolactin secretion induced by depolarizing $\mathrm{K}^{+}$in GH4C1 cells by blocking $\mathrm{Ca}^{2+}$ influx. Mol Cell Endocrinol 83: 79-84, 1992.

WEHNER F, OLSEN H, TINEL H, KINNE-SAFFRAN E, KINNE RKH: Cell volume regulation: osmolytes, osmolyte transport, and signal transduction. Rev Physiol Biochem Pharmacol 148: 1-80, 2003.

YANG XC, SACHS F: Block of stretch-activated ion channels in Xenopus oocytes by gadolinium and calcium ions. Science 243: 1068-1071, 1989.

ZHANG B, GLASGOW E, MURASE T, VERBALIS JG, GAINER H: Chronic hypoosmolality induces a selective decrease in magnocellular neurone soma and nuclear size in the rat hypothalamic supraoptic nucleus. J Neuroendocrinol 13: 29-36, 2001.

ZÓRAD S, ŠVÁBOVÁ E, KLIMEŠ I, MACHO L: Comparison of radiochemical purity and tissue binding of labeled insulin prepared by lactoperoxidase and chloramine T iodination. Endocrinol Exp 19: 267-275, 1985. 